\title{
FACILE SYNTHESIS, SOLUBLIZATION STUDIES AND ANTI-INFLAMMATORY ACTIVITY OF AMORPHOUS ZINC(II) CENTERED ALDIMINE COMPLEXES ${ }^{* *}$
}

\author{
Uzma ALI, ${ }^{\mathrm{a}}$ Aneela MAALIK, ${ }^{\mathrm{b}}$ Muhammad Babar TAJ,,${ }^{\mathrm{c}, \mathrm{d}}$ Ahmad RAHEEL,,${ }^{\mathrm{a}, *}$ \\ Ahmad Kaleem QURESHI, ${ }^{\mathrm{d}}$ Muhammad IMRAN, ${ }^{\mathrm{c}}$ Muhammad SHARIF, ${ }^{\mathrm{c}}$ \\ Syed Ahmad TIRMIZI, ${ }^{\mathrm{a}, *}$ Sadia NOOR, ${ }^{\mathrm{e}, *}$ and Heba ALSHATER ${ }^{\mathrm{f}}$ \\ ${ }^{a}$ Department of Chemistry, Quaid-e-Azam University Islamabad 44000, Pakistan \\ ${ }^{b}$ Department of Chemistry, Comsats University, Park Road, Chak Shahzad Islamabad 44000, Pakistan \\ ${ }^{c}$ Department of Chemistry, Islamia University Bahawalpur 63100, Pakistan. \\ ${ }^{\mathrm{d}}$ Department of Chemistry, University of Sahiwal 57000, Pakistan. \\ ${ }^{\mathrm{d}}$ Department of Chemistry, University of Agriculture, Faisalabad 38000, Pakistan \\ f Department of Forensic Medicine and Clinical Toxicology, Menoufia University Menofia 32871, Egypt
}

In this study, $\mathrm{Zn}$ (II) centered complexes with aldimine derivatives were synthesized using green solvent, polyethylene glycol (PEG-400) and amorphous complexes were characterized by FT-IR, multinuclear $\left({ }^{1} \mathrm{H}\right.$ and $\left.{ }^{13} \mathrm{C} N M R\right)$, elemental and thermal analysis. Thermogravimetric analysis indicated the extended thermal stability of the synthesized complexes. All the $\mathrm{Zn}$ (II) complexes show very significant photoexcitation in the range of $318-384 \mathrm{~nm}$ and photoemission in the range of $502-562 \mathrm{~nm}$. Among all the complexes, $\mathrm{Zn}$ (II) complex (3Zn) showed minimum band gap value, $2.35 \mathrm{eV}$. These amorphous complexes have been reported for their wide applications in biomedical sciences. The synthesized aldimine ligands and $\mathrm{Zn}$ (II) complexes were investigated for anti-inflammatory activity and these complexes showed more anti-inflammatory potential than the corresponding aldimine ligands. The solubilization of zinc complexes in sodium dodecyl sulphate was also investigated to reveal the interaction of metal complexes by using UV-Visible spectroscopy and electrical conductivity measurements.

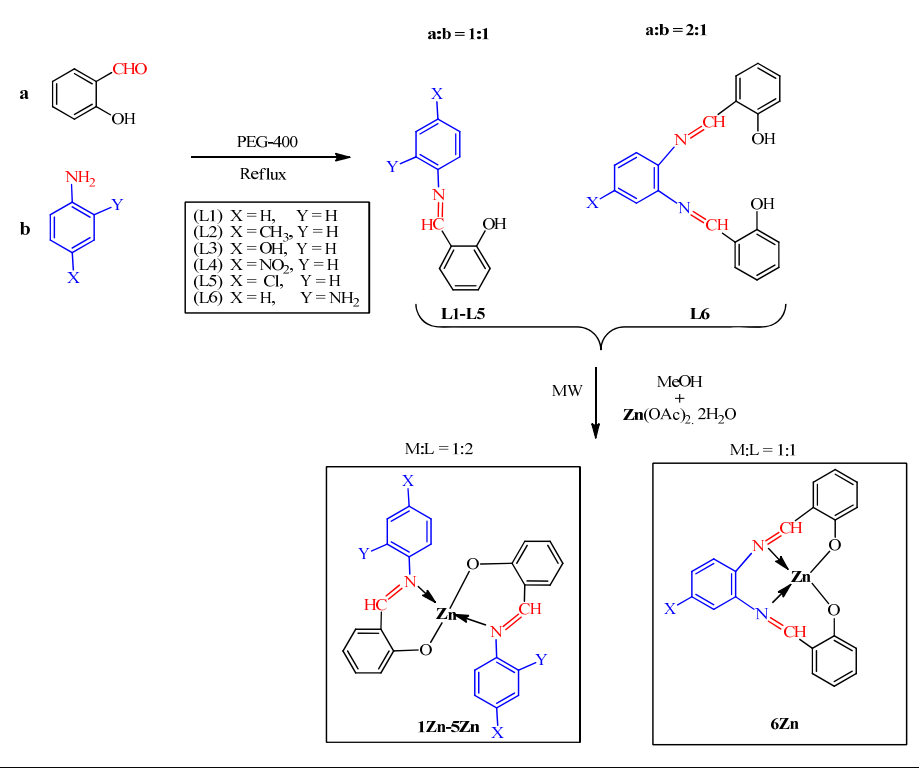

\section{INTRODUCTION}

Aldimines belong to a very vital class of compounds due to their wide range of applications in the field of medicine and they also act as ligands coordinating to various transition metals. ${ }^{1}$ The aldehydes with extended conjugation (aromatic aldehydes) give rise to stable aldimines derivatives (Schiff base) and they form more readily as compared to ketimines. ${ }^{2}$ Their contributions to

\footnotetext{
*Corresponding author: drbabartaj@gmail.com or ahmadraheel001@gmail.com or satirmizi_qau@yahoo.com or sadiaa613@gmail.com

${ }^{* *}$ Supplementary information on http://web.icf.ro/rrch/ or http://revroum.lew.ro/
} 
coordination chemistry cannot be taken for granted. The metal complexes in comparison with the organic compounds offer a variety of electronic structures linked with the coordination sphere, oxidation states and electronic configuration of metal. $^{3}$ They show many types of transitions including low energy ligand-to-metal charge transfer (LMCT), metal to ligand charge transfer (MLCT) and intra-ligand charge transfer (ILCT). ${ }^{4}$ The incorporation of metals within aldimine moieties bestows them some degree of antitumor, ${ }^{5}$ antifungal, ${ }^{6}$ antibacterial $^{7}$ and anti-inflammatory activities. ${ }^{8}$ The process of solubilization is a very valuable tool in understanding drug/excipient interaction with biomembranes and playing a vital role in many industrial and biological processes. ${ }^{8}$ The micelle formation is the most distinctive property of surfactants which allow metal complexes or drugs to solubilize to the greater extent. ${ }^{8}$

The structural features of these compounds also enhance several interesting properties such as photoluminescence. ${ }^{9}$ The metal-aldimine complexes, particularly $\mathrm{Zn}(\mathrm{II})$ centered salicylaldiminato compounds have also been previously reported for their use as greenish-white, blue, and red-light emitters in organic optoelectronics due to their high efficacy and stability. ${ }^{10}$ The ligand field stabilization effect and $\mathrm{d}^{10}$ configuration of the metal centered aldimine complexes mask and hinder the stereochemistry grooves. ${ }^{11}$ Due to the absence of d-d or metal-to-ligand transitions, $\mathrm{Zn}$ (II) complexes are optically more active, transparent than other related $\mathrm{d}^{\mathrm{n}}$ analogues. ${ }^{12}$

Keeping in view the literature, we are herein reporting the synthesis of six aldimine ligands and their $\mathrm{Zn}$ (II) complexes. The photoluminescence, antiinflammatory and solubilizations parameters of synthesized compounds have also been discussed.

\section{RESULTS AND DISCUSSION}

\section{Characterization of synthesized zinc complexes}

The green synthesis of aldimine ligands and their $\mathrm{Zn}$ (II) complexes are represented in Scheme 1. The synthesized $\mathrm{Zn}$ (II) complexes were insoluble in common organic solvents but soluble in DMSO and DMF. Many attempts were made to get single crystals of these complexes but unfortunately, we could not succeed. In the absence of single-crystal determination, the structures and geometry of zinc complexes were confirmed and characterized by elemental analysis along with other spectroscopic and thermal analyses. The elemental analyses showed that the metal-to-ligand ratio of $1: 2$ in all the complexes except $6 \mathrm{Zn}$ (1: 1). The $\mathrm{Zn}(\mathrm{II})$ complexes were amorphous, non-hygroscopic and coloured.

\section{FTIR analysis}

The bonding of the aldimine to $\mathrm{Zn}(\mathrm{II})$ ions was observed by a careful comparison of the infrared spectra of the $\mathrm{Zn}$ (II) complexes with those of the corresponding free aldimine ligands. A strong characteristic band appeared at $1603-1615 \mathrm{~cm}^{-1}$ because of $\mathrm{C}=\mathrm{N}$ stretching vibration, which indicated aldimine formation. A sharp peak for C-O stretching vibration of the phenolic hydroxyl group was spotted at $1255-1278 \mathrm{~cm}^{-1}$. Presence of $\mathrm{O}-\mathrm{H}$ stretching vibration at $3433-3494 \mathrm{~cm}^{-1}$ indicated the presence of water in the samples. This was due to the moisture contents in the samples. As these moisture contents have not appeared in the further analysis which has done after drying the sample for $2 \mathrm{~h}$ in the oven.

In IR spectra of complexes, the $\mathrm{C}=\mathrm{N}$ stretching vibration was observed to shift towards lower wavenumber indicated the presence of free ligand. This feature can be ascribed to the withdrawal of electron density from $\mathrm{N}$ atom owing to coordination. C-O stretching vibration became weaker in intensity in the spectra of complexes. New peaks observed in the regions of $434-516 \mathrm{~cm}^{-1}$ and $531-587 \mathrm{~cm}^{-1}$, were assigned to $\mathrm{Zn}-\mathrm{O}$ and $\mathrm{Zn}-\mathrm{N}$ stretching vibrations, respectively. These features suggested that the binding takes place through imine nitrogen and the phenolic oxygen atom of the aldimine to the $\mathrm{Zn}$ (II) ion forming tetrahedral geometry.

\section{Structural assignments by the mean NMR}

${ }^{1} \mathrm{H}$ NMR spectra of all the aldimines and their $\mathrm{Zn}(\mathrm{II})$ complexes were recorded in DMSO- $\mathrm{d}_{6}$. All the protons in the spectra were identified and the total number of calculated protons was found in good agreement with the proposed structures. The comparison of ${ }^{1} \mathrm{H}$ NMR data of aldimine ligands and $\mathrm{Zn}(\mathrm{II})$ complexes showed that the peak of the phenolic proton at $12.59-13.43$ ppm was observed in the spectra of free ligands. This peak was absent in the spectra of these complexes which suggests complexation through the phenolic oxygen. Singlet peak at $8.62-8.65 \mathrm{ppm}$ present in the spectra of 
aldimine L2 shifted toward the high field and appeared at $8.37 \mathrm{ppm}$ in the spectrum of $\mathrm{Zn}$ (II) complex. Aromatic protons gave multiple peaks in the ligands and a doublet with $\mathrm{J}$ values ranging from 7.8-8.4 Hz. In proton NMR spectrum of $\mathrm{Zn}$ (II) complex of aldimine $\mathbf{L 2}$ the multiplets then shifted to $7.20-7.23,6.94-7.08$ and $6.64-6.70 \mathrm{ppm}$ and the peak of methyl proton shifted to $2.29 \mathrm{ppm}$ owing to the coordination of zinc atom with the ligand.

${ }^{13} \mathrm{C}$ NMR spectra of the complexes were also recorded in DMSO- $\mathrm{d}_{6}$. In ${ }^{13} \mathrm{C}$ NMR spectra, the signal of the carbon attached to the hydroxyl group in the ligands was observed at 161-165.4 ppm, which shifted downfield at 171.32 and $171.17 \mathrm{ppm}$ respectively after complexation with the $\mathrm{Zn}$ (II) ions, which suggested bonding through this oxygen to the central zinc atom. The azomethine $(\mathrm{C}=\mathrm{N})$ carbon in ligands gave a signal at $160.4-161.3 \mathrm{ppm}$ which shifted down the field in the Zinc (II) complexes and appeared at 169.68 and 169.05 ppm, respectively. This deshielding of azomethine carbon on complexation further supported the involvement of nitrogen in complexation leading to the tetrahedral geometry of $\mathrm{Zn}(\mathrm{II})$ complexes.

\section{Thermal Analysis}

The thermal analysis data of the $\mathrm{Zn}$ (II) complexes is given in Table 1. The presence of lattice or coordinated water molecules was determined from TG curves. The weight losses of complexes were calculated within the temperature range at which the water molecules were removed. The values were used in the calculation of the number of water molecules attached to the metal complexes. The calculated weight loss due to water was calculated from the suggested molecular weight based on the Elemental Analysis data. The decomposition temperatures of the $\mathrm{Zn}$ (II) complexes were determined from the TG curves.

\section{Optical Properties}

\section{Optical Absorption Properties}

Absorption spectra of $\mathrm{Zn}$ (II) complexes were recorded in dilute chloroform solution $\left(10^{-6} \mathrm{~mol} \mathrm{~L}^{-1}\right)$. The positions of absorption bands are shown in Table 2. Three absorption bands were observed with $\lambda_{\max }$ at $236-292,316-327$ and $337-391 \mathrm{~nm}$, respectively. The high energy absorption bands were assigned to the spin-allowed singlet intra ligand ( $\left.{ }^{1} \mathrm{IL}\right)$ transition of the aldimine ligand. $\mathrm{Zn}$ (II) was not involved in electronic transitions in the UV-visible spectral region, and those absorptions in this region were assigned to ligandcentered (LC) $\pi-\pi^{*}$ transitions of the aldimine ligands. From these assignments, it was concluded that the HOMOs of the aldimine ligand systems were localized on the phenoxide units and the LUMOs were localizes at the imine groups.

Table 1

Thermal Analysis Data of Zn(II) Complexes

\begin{tabular}{l|c|c|c|c|c|c|c}
\hline Complex & \multirow{2}{*}{$\begin{array}{c}\text { Decomp. } \\
\text { steps }\end{array}$} & \multicolumn{2}{|c|}{ Water content } & \multicolumn{2}{c|}{ \% Wt. loss due to water } & \multirow{2}{*}{$\begin{array}{c}\text { Decomp. T } \\
\left({ }^{\circ} \mathbf{C}\right)\end{array}$} & \multirow{2}{*}{$\begin{array}{c}\text { Peak T } \\
\left({ }^{\circ} \mathbf{C}\right)\end{array}$} \\
\cline { 3 - 5 } \cline { 3 - 5 } & & Calcd. & Found & Calcd. & Found & & \\
\hline $\mathbf{1 Z n}$ & 2 & - & - & - & - & 281 & 389,529 \\
$\mathbf{2 Z n}$ & 2 & 0.57 & 2.96 & 2.06 & 9.92 & 272 & $110,403,559$ \\
$\mathbf{3 Z n}$ & 3 & 1.09 & 1.75 & 3.86 & 6.06 & 238 & $187,354,539$ \\
$\mathbf{4 Z n}$ & 2 & 0.36 & - & 1.18 & - & 300 & 357,524, \\
$\mathbf{5 Z n}$ & 2 & 1.68 & 1.31 & 7.42 & 5.86 & 430 & 192,546 \\
$\mathbf{6 Z n}$ & 2 & 3.62 & 3.19 & 12.82 & 11.46 & 384 & 192,546 \\
\hline
\end{tabular}

Table 2

UV-visible Absorption Data of $\mathrm{Zn}$ (II) Complexes

\begin{tabular}{c|c|c|c}
\hline Complex & $\boldsymbol{\pi}_{-\boldsymbol{\pi}^{*}} \mathbf{p h e n y l}(\mathbf{n m})$ & $\boldsymbol{\pi}-\boldsymbol{\pi}^{*} \mathbf{C}=\mathbf{N}(\mathbf{n m})$ & $\boldsymbol{\pi}-\boldsymbol{\pi}^{*} \mathbf{1} \mathbf{I L}(\mathbf{n m})$ \\
\hline $\mathbf{1 Z n}$ & 268 & 316 & 337 \\
$\mathbf{2 Z n}$ & 275 & 321 & 342 \\
$\mathbf{3 Z n}$ & 268 & 324 & 343 \\
$\mathbf{4 Z n}$ & 236 & 322 & 351 \\
$\mathbf{5 Z n}$ & 292 & 327 & 391 \\
$\mathbf{6 Z n}$ & 274 & 318 & 367 \\
\hline
\end{tabular}


Table 3

Photoluminescence Excitation and Emission Data of Zn(II) Complexes

\begin{tabular}{c|c|c|c}
\hline Complex & Excitation $\boldsymbol{\lambda}(\mathbf{n m})$ & Emission $\boldsymbol{\lambda}(\mathbf{n m})$ & Emission colour \\
\hline $\mathbf{1 Z n}$ & 335 & 533 & Green \\
$\mathbf{2 Z n}$ & 318 & 484 & Blue \\
$\mathbf{3 Z n}$ & 337 & 465 & Greenish blue \\
$\mathbf{4 Z n}$ & 326 & 562 & Yellowish green \\
$\mathbf{5 Z n}$ & 394 & 502 & Bluish-green \\
$\mathbf{6 Z n}$ & 369 & 536 & Bluish-green \\
\hline
\end{tabular}

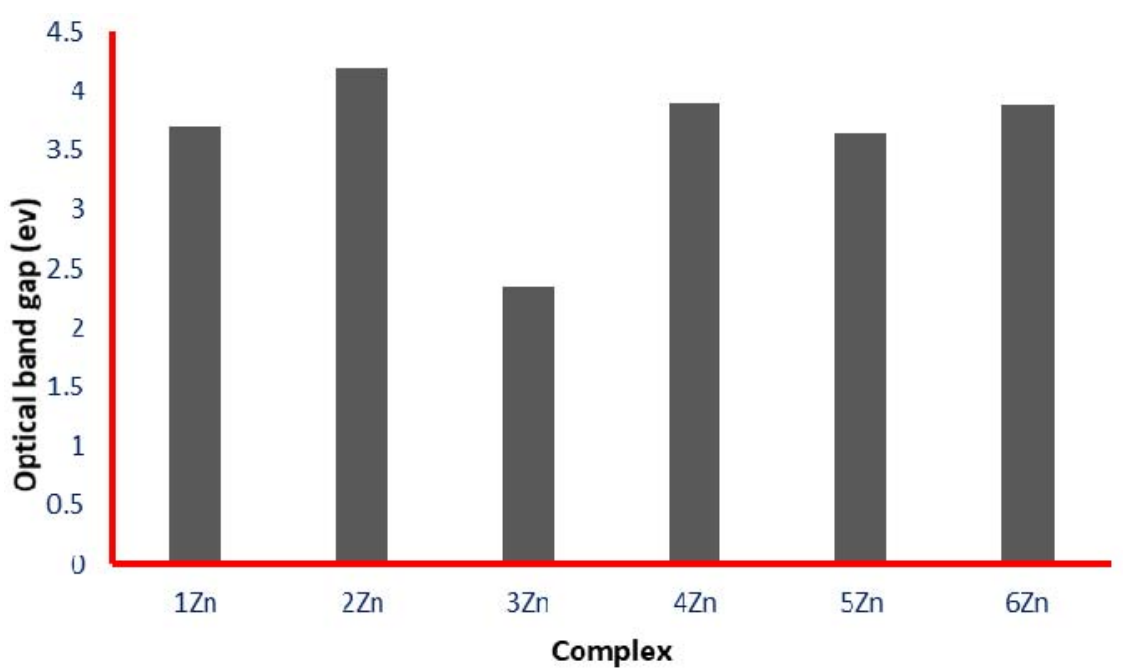

Fig. 1 - Optical Band Gaps of Zn(II) Complexes.

\section{Optical Excitation and Emission Properties}

The photoluminescence (PL) emission for the complexes in chloroform solution from blue to yellow span was assigned to intra ligand $\left(\pi^{*}-\pi\right)$ fluorescence. The excitation and emission wavelengths are summarized in Table 3.

As observed in the optical absorption results, the LUMO of the $\mathrm{Zn}$ (II) complexes were localized at the imine group. The LUMO level was destabilized with the addition of the electron-donating group. As a result, blue shifts in the emission maxima of $2 \mathrm{Zn}$ and $3 \mathrm{Zn}$ were observed concerning $1 \mathrm{Zn}$. Whereas the redshift is observed in the emission maximum of $4 \mathrm{Zn}$ as compared to $1 \mathrm{Zn}$.

\section{Optical Band Gap Determination}

Figure 2 shows the analysis of the optical absorption band edge of $\mathrm{Zn}$ (II) complexes in chloroform solutions. The optical bandgap of the films was determined by applying the Tauc model ${ }^{13}$, which was firstly but empirically proposed by Jellison and Modine in 1996.

The curves were determined by optical absorption spectra with the relationship following equation 10:

$$
\mathrm{ah} v=\mathrm{B}\left(\mathrm{h} v-\mathrm{E}_{\mathrm{g}}\right)^{\mathrm{n}}
$$

where a is absorption coefficient; $h$ is Plank's constant; $\mathrm{v}$ is frequency, $\mathrm{E}_{\mathrm{g}}$ is optical band gap; $\mathrm{B}$ is constant relation to the material; $n=1 / 2$ under the assumption of direct inter-band transition. The optical absorption coefficient, a, is calculated using the relation; $\mathrm{a}(\lambda)=2.303 \mathrm{~A}(\lambda) / \mathrm{L}$, where $\mathrm{a}=$ absorption coefficient in $\mathrm{m}^{-1}, \mathrm{~A}=$ absorbance in a.u., $\mathrm{L}=$ path length in meter.

Photon energy in eV was calculated using the relation: $\mathrm{E}=\mathrm{hv}=\mathrm{hc} / \lambda=1240(\mathrm{~nm}) \mathrm{eV} / \lambda(\mathrm{nm})$.

The optical band gap was evaluated by the energy value of the crossover point of the linear absorption band edge and energy axis. The values of the approximate optical band gaps $\mathrm{E}_{\mathrm{g}}$ obtained from the graphical relation are depicted in Figure 1.

As mentioned earlier the HOMOs of the aldimine ligand systems were localized on the phenoxide units and the LUMOs on the imine group and the LUMO level destabilized in the presence of electron-donating group and in turn the band gap between HOMO and LUMO levels was supposed to increase.

\section{Anti-inflammatory activity (bovine serum albumin test)}

BSA denaturation assay was employed to know the anti-inflammatory potential of aldimine ligands 
and their Zn(II) complexes (Figure 2). Broadly, the $\mathrm{Zn}$ (II) complexes showed more anti-inflammation than their corresponding aldimine ligands. The $\mathrm{Zn}$ (II) complex $6 \mathrm{Zn}$ show maximum inhibition of $88.27 \pm 2.0 \%$ at a maximum concentration of 500 $\mathrm{mg} \mathrm{mL} \mathrm{m}^{-1}$. This better inhibition as compared with the standard drug diclofenac sodium was possibly due to the strong coordination of metal with the ligand L6. This could also be attributed to the tetradentate nature of the ligand L6 causing stronger coordination with zinc as compared to other bidentate ligands (L1-L5). The results from our investigation were found in agreement with previously reported studies, which also indicated the enhancement of the anti-inflammatory activity of ligands upon coordination with the metal ions.
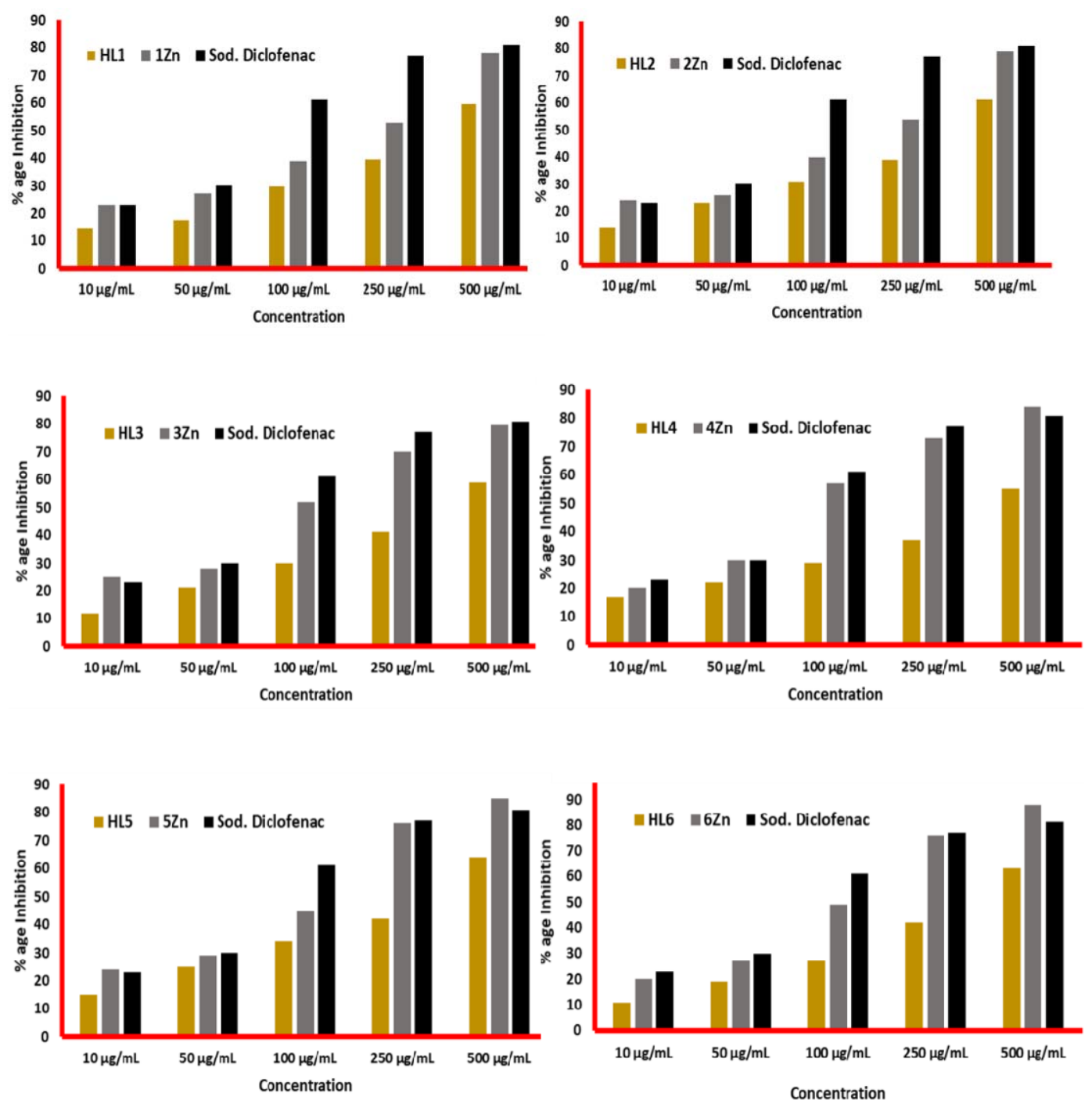

Fig. 2 - Anti-inflammatory evaluation of ligands (L1- L6) and their zinc complexes (1Zn-6Zn).

Mechanistically this enhancement of the antiinflammatory activity of $\mathrm{Zn}$ (II) complexes could be explained through Overtone's concept of cell permeability and Tweedy's theory of chelation. ${ }^{14}$ According to Overtone's concept, liposolubility is the major factor controlling the anti-inflammatory activity. ${ }^{15}$ As the lipid membrane around the cell allows the passage of only lipid-soluble molecules. On the other hand, in chelation polarity of the metal ion diminishes due to the overlapping of the ligand orbital and partial sharing of the positive charge of the metal ion with donor groups. Moreover, delocalization of $\pi$-electrons of metal chelate enhances the lipophilicity which results in the high penetration of metal complexes into the lipid membrane and blocks the metal-binding sites in the enzymes of pathogens. These metal complexes also disrupt the cell respiration process and thus block the proteins synthesis, which inhibit the growth of the pathogens. ${ }^{16}$ In general, metal complexes are more active than ligands as they may serve as principal cytotoxic species. 


\section{Solubilization of synthesized zinc complexes in micellar media of SDS}

The solubilization of zinc complexes (1Zn-6Zn) in the micellar media of SDS was investigated through conductometric and spectroscopic measurements.

\section{UV-Visible spectroscopic measurements}

Interaction of zinc complexes with SDS molecules was revealed by measuring simple and differential absorbance by UV-Visible spectroscopy. The values of maximum absorbance $\left(\lambda_{\max }\right)$ zinc complexes $(1 \mathrm{Zn}-6 \mathrm{Zn})$ in the absence and presence of the surfactant were recorded to assess the extent of interaction, as could be seen in Table 4. It was envisaged that the prevailing electrostatic and hydrophobic interactions influenced the molecules of zinc complexes to incorporate in the proximal regions of SDS micelles. There was a gradual increment in the absorption with increasing surfactant concentrations and the molecules of complexes incessantly interacted within the micelles hence their critical micellar concentration (CMC) increased. There was a bathochromic shift which indicated interactions of complexes with surfactant molecules in the micellar form.
Differential absorbance provides insight into the nature and existence of interactions of surfactants and complex molecules and provides understanding about their partitioning and binding trends in the micellar media. Among all complexes, 6Zn showed the highest tendency to partition towards the micelles of SDS while $4 \mathrm{Zn}$ was the on the lowest side. The partitioning law governed the behaviour of zinc complexes between aqueous and micellar media and partition coefficient $\left(K_{x}\right)$ helps in this evaluation (Table 5).

The plots representing simple (A) and differential absorbance $(\Delta \mathrm{A})$ of zinc complex against surfactant concentration to estimate the variations in CMC are shown in Figures 3 and 4.

There was an increasing trend for the CMC of surfactant (SDS) in the presence of zinc complexes due to their structure breaking effect. The solubilization parameters are summarized in Table 5. The penetration of zinc complex molecules into the micellar regions of SDS increased the values of CMC in comparison to pure SDS. The involvement of intermolecular hydrogen bonding between water and zinc complex molecules caused their adsorption in the periphery of surfactant micelles.

Table 4

The shift in the maximum absorbance of metal complexes in aqueous and micellar media

\begin{tabular}{c|c|c}
\hline Complex & $\begin{array}{c}\boldsymbol{\lambda}_{\max }(\mathbf{n m}) \\
\text { (aqueous media) }\end{array}$ & $\begin{array}{c}\boldsymbol{\lambda}_{\max }(\mathbf{n m}) \\
\text { (SDS micellar media) }\end{array}$ \\
\hline $\mathbf{1 Z n}$ & 268 & 293 \\
$\mathbf{2 Z n}$ & 274 & 307 \\
$\mathbf{3 Z n}$ & 347 & 376 \\
$\mathbf{4 Z n}$ & 336 & 367 \\
$\mathbf{5 Z n}$ & 390 & 421 \\
$\mathbf{6 Z n}$ & 309 & 343 \\
\hline
\end{tabular}

Table 5

Partitioning and binding parameters of zinc complexes in the micellar media of SDS

\begin{tabular}{|c|c|c|c|c|}
\hline Complex & $\mathbf{K}_{x}\left(\mathrm{dm}^{3} / \mathrm{mol}\right)$ & $\Delta \mathbf{G}_{p}(\mathrm{~kJ} / \mathrm{mol})$ & $\mathbf{K}_{\boldsymbol{b}}\left(\mathrm{dm}^{3} / \mathrm{mol}\right)$ & $\Delta \mathbf{G}_{\boldsymbol{b}}(\mathrm{kJ} / \mathrm{mol})$ \\
\hline $1 Z n$ & 13400 & -23.54 & 240 & -13.58 \\
\hline $2 Z n$ & 2510 & -19.39 & 70 & -10.53 \\
\hline $3 Z n$ & 2150 & -19 & 58.5 & -10.08 \\
\hline $4 Z n$ & 2000 & -18.82 & 80 & -10.85 \\
\hline $5 Z n$ & 5940 & -21.53 & 163 & -12.61 \\
\hline $6 \mathrm{Zn}$ & 19600 & -24.49 & 367 & -14.62 \\
\hline
\end{tabular}



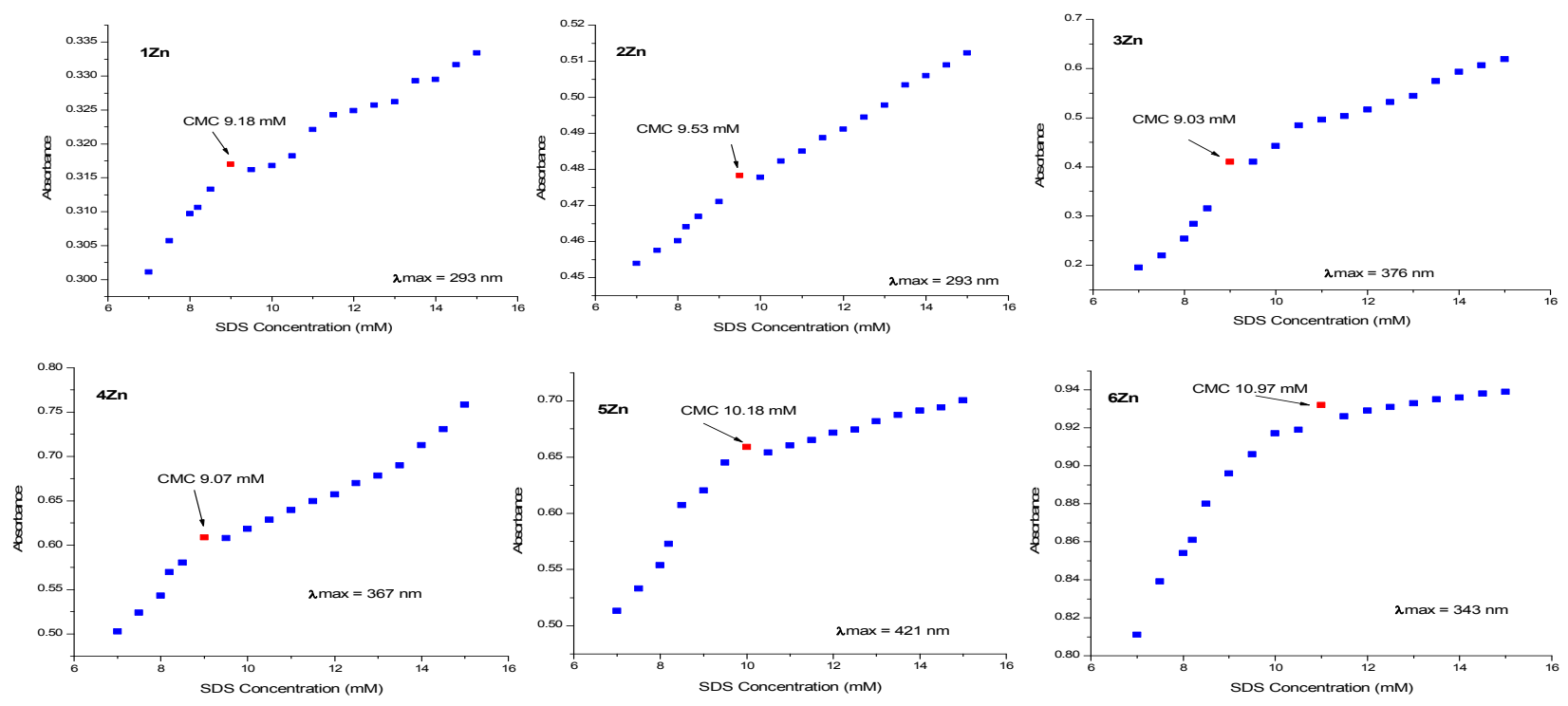

Fig. 3 - Simple absorbance of zinc complexes in the micellar media of SDS.
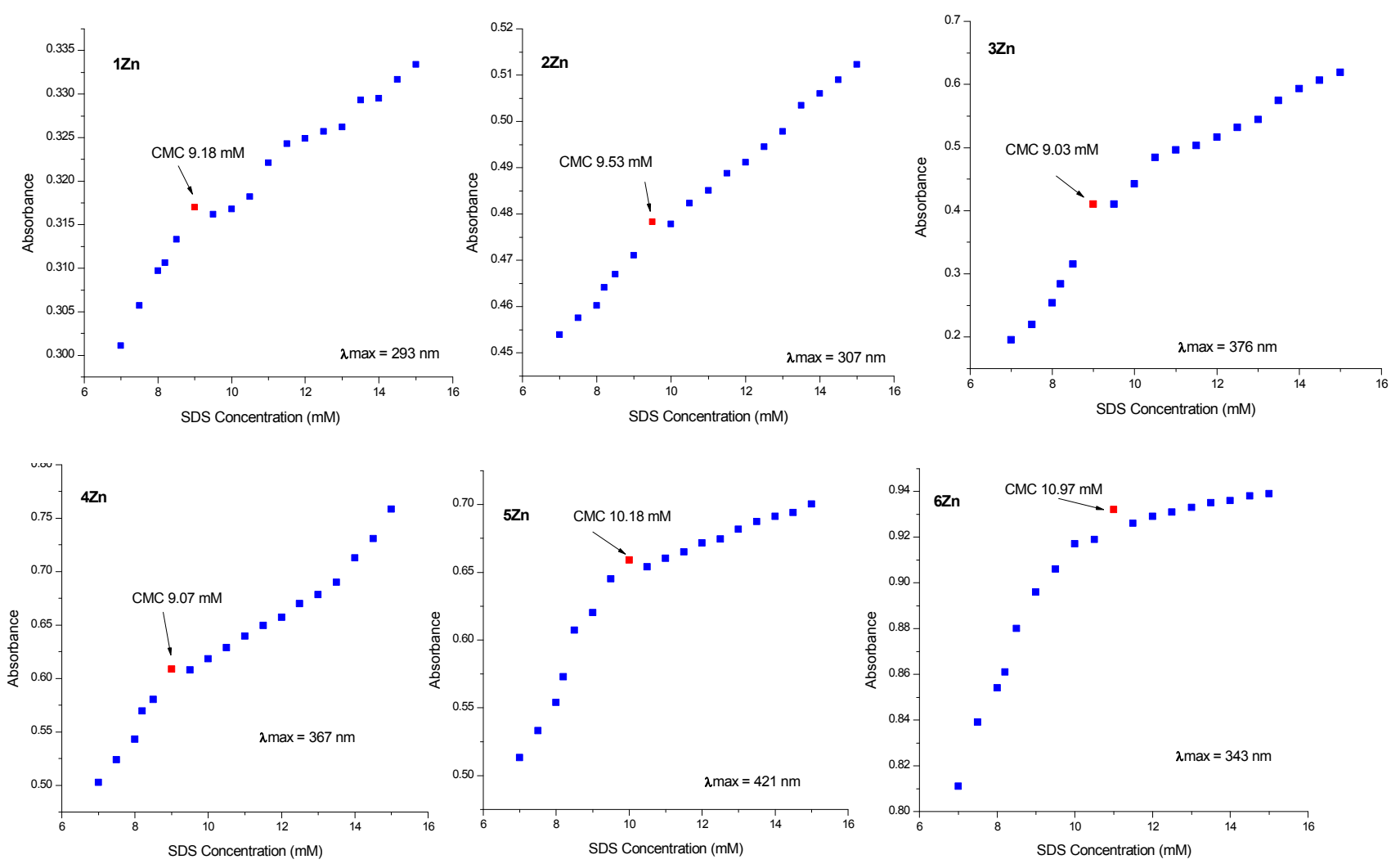

Fig. 4 - Differential absorbance of zinc complexes in the micellar media of SDS.

\section{Electrical conductivity measurements}

The thermodynamic parameters and the values $\mathrm{CMC}$ of zinc complexes (1Zn-6Zn) in the presence of SDS were explored using electrical conductivity data. It was observed that on gradual dilution, there was a noticeable change in the conductivity of the solutions. The experimental data was then compiled and calculated using equations 6-9 given in the experimental section. The results were graphically presented as plots of electrical conductivity (EC) against surfactant concentrations (CS) as elaborated in Figure 5. The value critical micellar concentration (CMC) was calculated from the point of intersection on two straight lines and with increasing temperature of solutions, this value increased. 



Fig. 5 - Graphical representation of electrical conductivity at various temperatures.

Table 6

Thermodynamic attributes of zinc complexes in the micellar media of SDS

\begin{tabular}{|c|c|c|c|c|c|c|}
\hline Complex & $\begin{array}{c}\mathbf{T} \\
\left({ }^{\circ} \mathrm{C}\right)\end{array}$ & $\begin{array}{l}\text { CMC } \\
(\mathrm{mM})\end{array}$ & $\begin{array}{c}\Delta \boldsymbol{G}_{\boldsymbol{m}} \\
\left(\mathrm{kJmol}^{-1}\right)\end{array}$ & $\begin{array}{c}\Delta \boldsymbol{H}_{\boldsymbol{m}} \\
\left(\mathrm{kJmo} \mathrm{l}^{-1}\right)\end{array}$ & $\begin{array}{c}\Delta \boldsymbol{S}_{\boldsymbol{m}} \\
\left(\mathrm{Jmol}^{-1} \mathrm{~K}^{-1}\right)\end{array}$ & $\beta$ \\
\hline $1 \mathrm{Zn}$ & $\begin{array}{l}25 \\
35 \\
45\end{array}$ & $\begin{array}{l}9.14 \\
9.51 \\
10.5\end{array}$ & $\begin{array}{l}-36.28 \\
-29.74 \\
-33.10\end{array}$ & $\begin{array}{l}-8.71 \\
-7.96 \\
-7.78\end{array}$ & $\begin{array}{l}92.52 \\
70.71 \\
79.65\end{array}$ & $\begin{array}{l}0.29 \\
0.54 \\
0.66\end{array}$ \\
\hline $2 Z n$ & $\begin{array}{l}25 \\
35 \\
45\end{array}$ & $\begin{array}{c}9.46 \\
10.02 \\
10.48\end{array}$ & $\begin{array}{l}-34.46 \\
-32.12 \\
-35.02\end{array}$ & $\begin{array}{c}-6 \\
-6.17 \\
-6.2\end{array}$ & $\begin{array}{l}95.52 \\
84.23 \\
90.63\end{array}$ & $\begin{array}{l}0.40 \\
0.46 \\
0.55\end{array}$ \\
\hline $3 Z n$ & $\begin{array}{l}25 \\
35 \\
45\end{array}$ & $\begin{array}{c}8.96 \\
9.8 \\
10 \\
\end{array}$ & $\begin{array}{l}-36.02 \\
-31.01 \\
-35.87\end{array}$ & $\begin{array}{l}-6.80 \\
-6.86 \\
-6.51\end{array}$ & $\begin{array}{l}98.09 \\
78.43 \\
92.34\end{array}$ & $\begin{array}{l}0.34 \\
0.43 \\
0.59\end{array}$ \\
\hline $4 Z n$ & $\begin{array}{l}25 \\
35 \\
45\end{array}$ & $\begin{array}{c}9 \\
10.03 \\
10.56\end{array}$ & $\begin{array}{l}-36.33 \\
-31.58 \\
-35.73\end{array}$ & $\begin{array}{c}-10.0 \\
-10.03 \\
-9.69\end{array}$ & $\begin{array}{l}88.38 \\
69.99 \\
81.88\end{array}$ & $\begin{array}{l}0.32 \\
0.42 \\
0.57\end{array}$ \\
\hline $5 Z n$ & $\begin{array}{l}25 \\
35 \\
45\end{array}$ & $\begin{array}{l}10.12 \\
11.99 \\
12.04\end{array}$ & $\begin{array}{l}-35.17 \\
-32.84 \\
-34.62\end{array}$ & $\begin{array}{l}-5.91 \\
-5.89 \\
-6.08\end{array}$ & $\begin{array}{l}98.19 \\
87.50 \\
89.74\end{array}$ & $\begin{array}{c}0.35 \\
0.46 \\
0.5\end{array}$ \\
\hline $6 \mathrm{Zn}$ & $\begin{array}{l}25 \\
35 \\
45\end{array}$ & $\begin{array}{c}11 \\
11.24 \\
11.59\end{array}$ & $\begin{array}{l}-33.14 \\
-32.42 \\
-33.88\end{array}$ & $\begin{array}{c}-5.6 \\
-5.77 \\
-6.05\end{array}$ & $\begin{array}{l}92.41 \\
86.53 \\
87.51\end{array}$ & $\begin{array}{l}0.43 \\
0.49 \\
0.51\end{array}$ \\
\hline
\end{tabular}

There was significant interaction in zinc complex with the micelles of surfactant and the thermodynamic parameters are summarized in Table 6. The negative values of $\Delta H_{m}$ and $\Delta G_{m}$ indicated that micellization was an exothermic process and it favoured the stability and spontaneity of the system. This process was also entropy-driven as could be seen in the positive 
values of entropy $\left(\Delta S_{m}\right)$, due to significantly transferring hydrophobic tails from aqueous to the core micellar zone.

\section{Comparative interaction of selected metal complexes with SDS}

The results obtained from UV-Visible spectroscopy and those of electrical conductivity were in close agreement in terms of CMC. The highest partitioning coefficient $\left(19600 \mathrm{dm}^{3} / \mathrm{mol}\right)$ and binding constant $(367 \mathrm{~kJ} / \mathrm{mol})$ of $6 \mathrm{Zn} / \mathrm{SDS}$ system among other complexes, indicated it highest partitioning between micellar and aqueous medium. As a result of this phenomenon of partitioning and binding, $6 \mathrm{Zn}$ molecules remained near the peripheral zone of SDS micelles while other complexes positioned them in their corresponding regions depending on their partitioning and binding values. Though the micellization phenomenon has not been fully explained, yet we can assign some generalizations to this process. The highest negative value $\Delta G_{p}$ ($24.49 \mathrm{~kJ} / \mathrm{mol}$ ) of $6 \mathrm{Zn} / \mathrm{SDS}$ system indicated the stability and spontaneity of the system. The position of the zinc complex molecules in various regions of the SDS micelles was determined from the values of partitioning coefficients. The higher value of $K_{x}$ positions the location of the molecules in the outer zone of the micelles whereas the molecules with the lowest value would stay deep inside the core region as could be witnessed in Scheme 2.
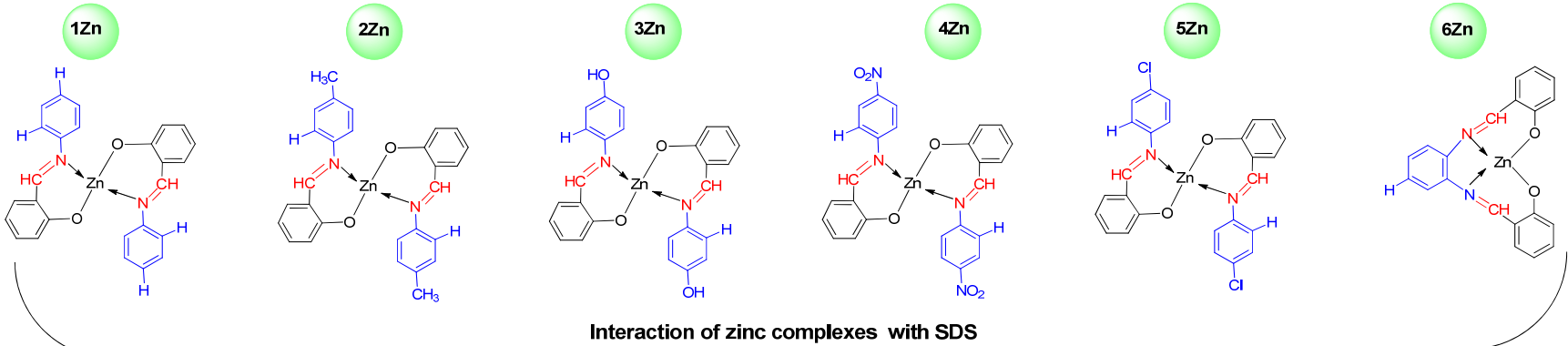

Interaction of zinc complexes with SDS

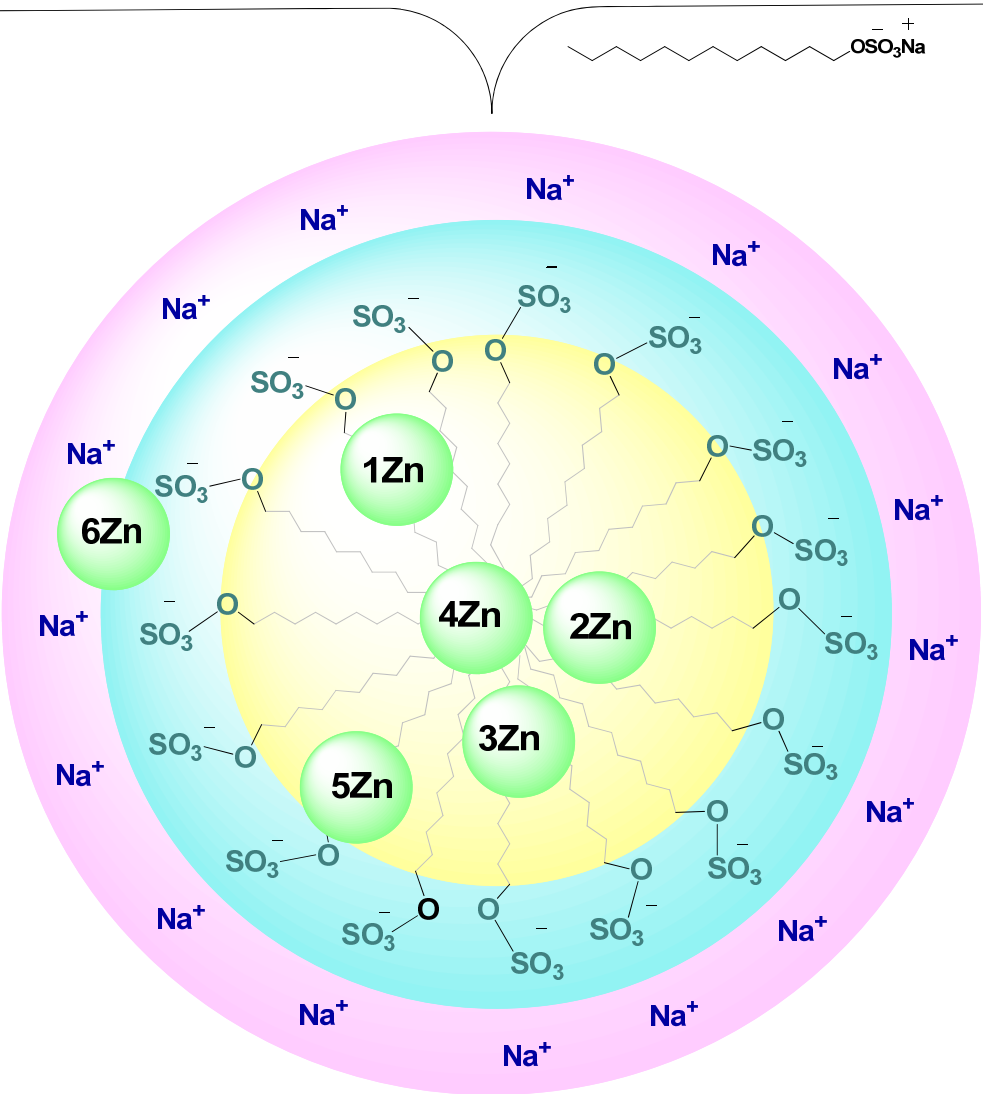

Scheme 2 - Location of zinc complexes in various regions of SDS micelles. 


\section{EXPERIMENTAL}

\section{Materials and Chemicals}

The chemicals used for synthesis were polyethylene glycol $\left(\mathrm{PEG}_{400}\right)$, salicylaldehyde, aniline, p-toluidine, 4-aminophenol, 4-nitroaniline, 1,2-diaminobenzene, 1,4-diaminobenzene, Zinc acetate dehydrate, an anionic surfactant, sodium dodecyl sulphate (SDS) and the solvents methanol and chloroform, purchased from Fluka (Switzerland), Sigma Aldrich (Germany), E-Merck (Germany). All solvents were used without further purification. Elemental analysis was performed by Perkin-Elmer CHNS elemental analyser. The FTIR spectral data were recorded on Bio-Rad Merlin spectrophotometer using $\mathrm{KBr}$ discs. The ${ }^{1} \mathrm{HNMR}(300 \mathrm{MHz})$ and ${ }^{13} \mathrm{C}$ NMR $(75.43$ $\mathrm{MHz}$ ) spectra were recorded on Bruker AM-250 spectrometers in $\mathrm{CDCl}_{3}$, solution using TMS as an internal standard. TG curves were obtained by Perkin-Elmer TGA 7 simultaneous thermal analyser. UV-visible absorption spectra were recorded on Perkin-Elmer Lambda-20 UV-visible spectrophotometer from 200-800nm range. Photoluminescence spectra were recorded on Perkin-Elmer LS 55 luminescence spectrophotometer.

\section{General procedure for the synthesis of ligands (L1-L6)}

The substituted aniline $(0.01 \mathrm{~mol})$ and salicylaldehyde $(0.01 \mathrm{~mol})$ were added in a hot stirred solution of PEG-400 $(40 \mathrm{ml})$ followed by a few drops of $5 \% \mathrm{HCl}$ solution. The mixture was refluxed for one hour and then placed in an icewater bath until the formation of precipitates. The products were filtered, washed, dried, and recrystallized from warm ethanol to get the pure aldimine ligands.

2-((phenylimino)methyl)phenol (L1)

Yellow ppt. $75 \%$ mp $55^{\circ} \mathrm{C}$; IR spectrum, v, $\mathrm{cm}^{-1}: 3430$ $(\mathrm{OH}), 3051(=\mathrm{C}-\mathrm{H}$ arom. $), 1615(\mathrm{C}=\mathrm{N}), 1530,1480(\mathrm{C}=\mathrm{C}$ arom.), 1273 (C-O); ${ }^{1} \mathrm{H}-\mathrm{NMR}$ spectrum $\left(300 \mathrm{MHz}, \mathrm{DMSO}-\mathrm{d}_{6}\right)$ $\delta_{\mathrm{H}}, \mathrm{ppm}$ : 6.95-6.99 (J=7.8 Hz, 1H, m), 7.04-7.07 (1H, d), 7.28$7.33(3 \mathrm{H}, \mathrm{m}), 7.38-7.48(4 \mathrm{HAr}, \mathrm{m}), 8.65(1 \mathrm{H}$, ammine, s), $13.30\left(1 \mathrm{H}\right.$, phenolic, s); ${ }^{13} \mathrm{C}-\mathrm{NMR}$ spectrum $(75 \mathrm{MHz}$, DMSO$\left.\mathrm{d}_{6}\right) \delta_{\mathrm{C}}$, ppm: 117.27, 148.51, 161.13, 162.70; Calculated, \%: C 79.17; H 5.62; N 7.10. $\mathrm{C}_{13} \mathrm{H}_{11} \mathrm{NO}$ (197.24). Found, \%: C 80.02; H 5.03; N 7.92.

\section{2-((p-tolylimino $)$ methyl $)$ phenol (L2)}

Bright yellow ppt. $86 \%$ mp $96^{\circ} \mathrm{C}$; IR spectrum, $v, \mathrm{~cm}^{-1}$ : $3436(\mathrm{OH}), 3031$ (=C-H arom.), $2950\left(\mathrm{C}-\mathrm{H} \mathrm{sp}{ }^{3}\right), 1615(\mathrm{C}=\mathrm{N})$, 1561, 1498 (C=C arom.), 1278 (C-O); ${ }^{1} \mathrm{H}-\mathrm{NMR}$ spectrum $\left(300 \mathrm{MHz}, \mathrm{DMSO}-\mathrm{d}_{6}\right) \delta_{\mathrm{H}}, \mathrm{ppm}: 2.41\left(3 \mathrm{H}, \mathrm{CH}_{3}, \mathrm{~s}\right), 6.94-6.99$ $(\mathrm{J}=7.8 \mathrm{~Hz}, 1 \mathrm{H}, \mathrm{m}), 7.04-7.06(1 \mathrm{H}, \mathrm{d}), 7.21-7.28(4 \mathrm{H}, \mathrm{m}), 7.30-$ 7.42 (2HAr, m), $8.64(1 \mathrm{H}$, ammine, s), $13.43(1 \mathrm{H}$, phenolic, $\mathrm{s}) ;{ }^{13} \mathrm{C}$-NMR spectrum (75 MHz, DMSO-d $\left.\mathrm{d}_{6}\right) \delta_{\mathrm{C}}, \mathrm{ppm}: 161.12$, 161.72; Calculated, \%: C 79.59; H 6.20; N 6.63. $\mathrm{C}_{14} \mathrm{H}_{13} \mathrm{NO}$ (211.26). Found, \%: C 80.21; H 7.06; N 6.76.

2-(((4-hydroxyphenyl)imino)methyl)phenol (L3)

Red ppt. $72 \%$. mp $143-144^{\circ} \mathrm{C}$; IR spectrum, $\mathrm{v}, \mathrm{cm}^{-1}: 3436$ $(\mathrm{OH}), 3031(=\mathrm{C}-\mathrm{H}$ arom. $), 1614(\mathrm{C}=\mathrm{N}), 1503,1453(\mathrm{C}=\mathrm{C}$ arom.), 1255 (C-O); ${ }^{1} \mathrm{H}-\mathrm{NMR}$ spectrum (300 MHz, DMSO-d ${ }_{6}$ ) $\delta_{\mathrm{H}}, \mathrm{ppm}: 6.90-6.98(\mathrm{~J}=7.8 \mathrm{~Hz}, 1 \mathrm{H}, \mathrm{m}), 7.03-7.05(1 \mathrm{H}, \mathrm{d}), 7.23-$ $7.28(2 \mathrm{H}, \mathrm{m}), 7.35-7.41$ (2HAr, m), $8.62(1 \mathrm{H}$, ammine, s), $13.43\left(1 \mathrm{H}\right.$, phenolic, s); ${ }^{13} \mathrm{C}-\mathrm{NMR}$ spectrum (75 MHz, DMSO$\left.\mathrm{d}_{6}\right) \quad \delta_{\mathrm{C}}, \quad$ ppm: $116.16-141.36, \quad 154.95, \quad 160.49, \quad 160.98$; Calculated, \%: C 77.23; H 5.20; N 6.57. $\mathrm{C}_{13} \mathrm{H}_{11} \mathrm{NO}_{2}$ (213.24). Found, \%: C 77.21; H 4.64; N 6.01.

\section{2-(((4-nitrophenyl)imino)methyl)phenol (L4)}

Orange ppt. $70 \%$. mp $160-161^{\circ} \mathrm{C}$; IR spectrum, $v, \mathrm{~cm}^{-1}$ : $3466(\mathrm{OH}), 3046$ (=C-H arom.), $1604(\mathrm{C}=\mathrm{N}), 1509,1458$
$(\mathrm{C}=\mathrm{C}$ arom. $), 1338,1508 \quad\left(\mathrm{NO}_{2}\right), 1269$ (C-O); ${ }^{1} \mathrm{H}-\mathrm{NMR}$ spectrum $\left(300 \mathrm{MHz}, \mathrm{DMSO}-\mathrm{d}_{6}\right) \delta_{\mathrm{H}}, \mathrm{ppm}: 6.98-7.03(\mathrm{~J}=8.1 \mathrm{~Hz}$, $1 \mathrm{H}, \mathrm{m}), 7.05-7.08(1 \mathrm{H}, \mathrm{d}), 7.36-7.41(2 \mathrm{H}, \mathrm{m}), 7.44-7.50$ (2HAr, m), 8.29-8.34 (2H, m), $8.65(1 \mathrm{H}$, ammine, s), 12.59 $\left(1 \mathrm{H}\right.$, phenolic, s); ${ }^{13} \mathrm{C}-\mathrm{NMR}$ spectrum $\left(75 \mathrm{MHz}, \mathrm{DMSO}-\mathrm{d}_{6}\right)$ $\delta_{\mathrm{C}}, \mathrm{ppm}: 117.55-154.21,161.33,165.41$; Calculated, \%: C 64.46; $\mathrm{H}$ 4.16; $\mathrm{N}$ 11.56. $\mathrm{C}_{13} \mathrm{H}_{10} \mathrm{~N}_{2} \mathrm{O}_{3}$ (242.23). Found, \%: $\mathrm{C}$ 64.21; H 4.41; N 10.89.

2-(((4-chlorophenyl)imino)methyl)phenol (L5)

Grey ppt. $60 \%$ mp $134-136^{\circ} \mathrm{C}$; IR spectrum, $v, \mathrm{~cm}^{-1}$ : $3467(\mathrm{OH}), 3045$ (=C-H arom.), $1609(\mathrm{C}=\mathrm{N}), 1519,1460$ $\left(\mathrm{C}=\mathrm{C}\right.$ arom.), 1260 (C-O); ${ }^{1} \mathrm{H}-\mathrm{NMR}$ spectrum $(300 \mathrm{MHz}$, DMSO-d $\left.{ }_{6}\right) \delta_{\mathrm{H}}$, ppm: 6.96-7.04 $(\mathrm{J}=8.1 \mathrm{~Hz}, 1 \mathrm{H}, \mathrm{m}), 7.06-7.09$ (1H, d), 7.33-7.39 (2H, m), 7.40-7.47 (2HAr, m), 8.22-8.35 $(2 \mathrm{H}, \mathrm{m}), 8.67\left(1 \mathrm{H}\right.$, ammine, s), $12.50\left(1 \mathrm{H}\right.$, phenolic, s); ${ }^{13} \mathrm{C}-$ NMR spectrum (75 MHz, DMSO-d ${ }_{6}$ ) $\delta_{\mathrm{C}}$, ppm: 116.42-153.33, 162.34, 166.31; Calculated, \%: C 67.40; H 4.35; N 6.05. $\mathrm{C}_{13} \mathrm{H}_{10} \mathrm{ClNO}$ (231.68). Found, \%: C 68.29; H 3.96; N 6.71.

2-(((2-aminophenyl)imino)methyl)phenol (L6)

Yellow ppt. $80 \%$. mp $163-164^{\circ} \mathrm{C}$; IR spectrum, $v, \mathrm{~cm}^{-1}$ : $3450(\mathrm{OH}), 3051(=\mathrm{C}-\mathrm{H}$ arom. $), 1609(\mathrm{C}=\mathrm{N}), 1560,1479$ $\left(\mathrm{C}=\mathrm{C}\right.$ arom.), 1274 (C-O); ${ }^{1} \mathrm{H}-\mathrm{NMR}$ spectrum (300 MHz, DMSO-d $\left.{ }_{6}\right) \delta_{\mathrm{H}}$, ppm: 6.92-6.97 $(\mathrm{J}=8.1 \mathrm{~Hz}, 1 \mathrm{H}, \mathrm{m}), 7.06-7.09$ $(1 \mathrm{H}, \mathrm{d}), 7.24-7.28(2 \mathrm{H}, \mathrm{m}), 7.35-7.42(2 \mathrm{HAr}, \mathrm{m}), 8.65(1 \mathrm{H}$, ammine, s), $13.08(1 \mathrm{H}$, phenolic, $\mathrm{s}) ;{ }^{13} \mathrm{C}-\mathrm{NMR}$ spectrum $(75$ MHz, DMSO-d $\left.{ }_{6}\right) \delta_{\mathrm{C}}$, ppm: 117.58-142.58, 163.73, 166.36; Calculated, \%: C 75.93; H 5.10; $\mathrm{N} 8.86 . \mathrm{C}_{20} \mathrm{H}_{16} \mathrm{~N}_{2} \mathrm{O}_{2}$ (316.36). Found, \%: C 76.57; H 9.02; N 8.88.

\section{General procedure for the synthesis of $\mathrm{Zn}$ (II) complexes (1Zn-6Zn)}

$15 \mathrm{~mL}$ of methanolic solutions of zinc acetate dihydrate $(0.01 \mathrm{~mol})$ and $15 \mathrm{~mL}$ of aldimine ligand $(0.01 \mathrm{~mol})$ were mixed in a $100 \mathrm{~mL}$ flask equipped with a reflux condenser fitted in the domestic microwave oven. The mixture was heated at $150{ }^{\circ} \mathrm{C}$ for 20 minutes. The precipitates were filtered and washed with methanol to get the amorphous product. Unfortunately, no crystalline products suitable for single crystal XRD analysis were obtained.

Zn(2-((phenylimino)methyl)phenol $)_{2}(\mathbf{1 Z n})$

Yellowish green solid. $83 \%$. mp $184-186^{\circ} \mathrm{C}$; IR spectrum, v, $\mathrm{cm}^{-1}$ : 3051 (=C-H arom.), $1604(\mathrm{C}=\mathrm{N}), 1531,1484(\mathrm{C}=\mathrm{C}$ arom.), 1251 (C-O), 537 (Zn-O), 488 (Zn-N); ${ }^{1} \mathrm{H}-\mathrm{NMR}$ spectrum (300 MHz, DMSO-d $\left.{ }_{6}\right) \delta_{\mathrm{H}}, \mathrm{ppm}: 6.96-6.98(\mathrm{~J}=7.7 \mathrm{~Hz}, 1 \mathrm{H}, \mathrm{m}), 7.06-7.08$ (1H, d), 7.38-7.43 (1HAr, m), 8.37 (1H, ammine, s); ${ }^{13} \mathrm{C}-\mathrm{NMR}$ spectrum $\left(75 \mathrm{MHz}, \mathrm{DMSO}-\mathrm{d}_{6}\right) \delta_{\mathrm{C}}$, ppm: 115-162, 169, 171; Calculated, \%: C 68.21; $\mathrm{H} 4.40 ; \mathrm{N}$ 6.12. $\mathrm{C}_{26} \mathrm{H}_{20} \mathrm{~N}_{2} \mathrm{O}_{2} \mathrm{Zn}$ (457.84). Found, \%: C 69.58; H 4.06; N 6.48.

\section{Zn(2-((p-tolylimino $)$ methyl $)$ phenol $)_{2}(\mathbf{2 Z n})$}

Yellowish solid, $73 \%$. mp $191-193^{\circ} \mathrm{C}$; IR spectrum, $v, \mathrm{~cm}^{-1}$ : 3031 (=C-H arom.), $2990\left(\mathrm{C}-\mathrm{H} \mathrm{sp}{ }^{3}\right), 1585(\mathrm{C}=\mathrm{N}), 1527,1448$ $\left(\mathrm{C}=\mathrm{C}\right.$ arom.), 1250 (C-O), 584 (Zn-O), $500(\mathrm{Zn}-\mathrm{N}) ;{ }^{1} \mathrm{H}-\mathrm{NMR}$ spectrum $\left(300 \mathrm{MHz}, \mathrm{DMSO}-\mathrm{d}_{6}\right) \delta_{\mathrm{H}}, \mathrm{ppm}: 2.29(3 \mathrm{H}, \mathrm{s}), 6.64-6.70$ $(\mathrm{J}=7.7 \mathrm{~Hz}, 1 \mathrm{H}, \mathrm{m}), 6.94-7.08(5 \mathrm{H}, \mathrm{m}), 7.20-7.23(1 \mathrm{H}, \mathrm{q}), 7.36-7.41$ (1Har, m), $8.37\left(1 \mathrm{H}\right.$, ammine, s); ${ }^{13} \mathrm{C}-\mathrm{NMR}$ spectrum $(75 \mathrm{MHz}$, DMSO-d $\left.{ }_{6}\right) \delta_{\mathrm{C}}, \quad$ ppm: 21.11, 115.11-161.73, 169.05, 171.17; Calculated, \%: $\mathrm{C}$ 69.2; $\mathrm{H}$ 4.98; N 5.77. $\mathrm{C}_{28} \mathrm{H}_{24} \mathrm{~N}_{2} \mathrm{O}_{2} \mathrm{Zn}$ (485.89). Found, \%: C 68.49; H 4.35; N 5.87.

Zn(2-(((4-hydroxyphenyl)imino)methyl) phenol $)_{2}$ (3Zn)

Yellowish solid, $73 \%$. mp $191-193^{\circ} \mathrm{C}$; IR spectrum, v, $\mathrm{cm}^{-1}$ : 3019 (=C-H arom.), $1594(\mathrm{C}=\mathrm{N}), 1509,1438(\mathrm{C}=\mathrm{C}$ arom.), 1276 (C-O), 587 (Zn-O), 501 (Zn-N); ${ }^{1} \mathrm{H}-\mathrm{NMR}$ spectrum $\left(300 \mathrm{MHz}, \mathrm{DMSO}-\mathrm{d}_{6}\right) \delta_{\mathrm{H}}, \mathrm{ppm}: 3.17(1 \mathrm{H}, \mathrm{s}), 6.61-$ $6.72(\mathrm{~J}=7.13 \mathrm{~Hz}, 4 \mathrm{H}, \mathrm{m}), 7.12-7.15(\mathrm{~J}=7.32,2 \mathrm{H}, \mathrm{d}), 7.30-7.35$ 
$(\mathrm{J}=7.48,1 \mathrm{H}, \mathrm{t}), 7.48-7.49(1 \mathrm{HAr}, \mathrm{d}), 8.71(1 \mathrm{H}$, ammine, $\mathrm{s}) ;{ }^{13} \mathrm{C}-$ NMR spectrum $\left(75 \mathrm{MHz}, \mathrm{DMSO}-\mathrm{d}_{6}\right) \delta_{\mathrm{C}}, \mathrm{ppm}: 115.02-157.08$, 168.65, 170.65; Calculated, \%: C 63.75; H 4.12; N 5.72. $\mathrm{C}_{26} \mathrm{H}_{20} \mathrm{~N}_{2} \mathrm{O}_{4} \mathrm{Zn}$ (489.84). Found, \%: $\mathrm{C}$ 63.21; H 4.06; N 5.88.

Zn(2-(((4-nitrophenyl)imino)methyl)phenol) ${ }_{2}(\mathbf{4 Z n})$

Orange shiny powder. $85 \%$. $\mathrm{mp}>300^{\circ} \mathrm{C}$; IR spectrum, $v$, $\mathrm{cm}^{-1}: 3046(=\mathrm{C}-\mathrm{H}$ arom. $), 1599(\mathrm{C}=\mathrm{N}), 1508,1451(\mathrm{C}=\mathrm{C}$ arom.), $1324\left(\mathrm{NO}_{2}\right), 1254$ (C-O), $583(\mathrm{Zn}-\mathrm{O}), 415(\mathrm{Zn}-\mathrm{N}) ;{ }^{1} \mathrm{H}-$ NMR spectrum $\left(300 \mathrm{MHz}, \mathrm{DMSO}-\mathrm{d}_{6}\right) \delta_{\mathrm{H}}$, ppm: 7.01-7.09 $(\mathrm{J}=7.42 \mathrm{~Hz}, 2 \mathrm{H}, \mathrm{q}), 7.38-7.47 \quad(\mathrm{~J}=8.33,4 \mathrm{H}, \mathrm{q}), 8.32-8.34$ (2HAr, d), $8.65\left(1 \mathrm{H}\right.$, ammine, s); ${ }^{13} \mathrm{C}-\mathrm{NMR}$ spectrum $(75$ MHz, DMSO- $\left.\mathrm{d}_{6}\right) \delta_{\mathrm{C}}, \mathrm{ppm}: 117.55-154.21,161.33,165.41$; Calculated, \%: C 57.00; H 3.31; N 10.23. $\mathrm{C}_{26} \mathrm{H}_{18} \mathrm{~N}_{4} \mathrm{O}_{6} \mathrm{Zn}$ (547.83). Found, \%: C 48.91; H 3.06; N 10.18.

Zn(2-(((4-chlorophenyl)imino)methyl) phenol $)_{2}(\mathbf{5 Z n})$

Grey solid. $80 \%$. mp $>300^{\circ} \mathrm{C}$; IR spectrum, v, $\mathrm{cm}^{-1}: 3014$ $(=\mathrm{C}-\mathrm{H}$ arom. $), 1587(\mathrm{C}=\mathrm{N}), 1567,1450(\mathrm{C}=\mathrm{C}$ arom. $), 1251$ (C-O), 532 (Zn-O), 476 (Zn-N); ${ }^{1} \mathrm{H}-\mathrm{NMR}$ spectrum (300 MHz, DMSO-d $\left.{ }_{6}\right) \delta_{\mathrm{H}}, \mathrm{ppm}: 6.59-6.66(\mathrm{~J}=6.33 \mathrm{~Hz}, 1 \mathrm{H}, \mathrm{t}), 6.71-$ $6.74(\mathrm{~J}=6.71 \mathrm{~Hz}, 1 \mathrm{H}, \mathrm{d}) 7.25-7.31(1 \mathrm{H}, \mathrm{m}), 7.45-7.52(2 \mathrm{H}, \mathrm{m})$, 7.89-7.94 (1HAr, m), 8.45 (1H, ammine, s); ${ }^{13} \mathrm{C}-\mathrm{NMR}$ spectrum $\left(75 \mathrm{MHz}\right.$, DMSO-d $\left.\mathrm{d}_{6}\right) \delta_{\mathrm{C}}$, ppm: 113.32-120.32, 165.19, 170.75; Calculated, \%: C 59.29; H 3.44; N 5.32. $\mathrm{C}_{26} \mathrm{H}_{18} \mathrm{~N}_{2} \mathrm{O}_{2} \mathrm{Cl}_{2} \mathrm{Zn}$ (526.72). Found, \%: C 58.98; H 5.26; N 5.28 .

\section{Zn(2-(((2-aminophenyl)imino)methyl)phenol) (6Zn)}

Orange shiny powder. $83 \% . \mathrm{mp}>300^{\circ} \mathrm{C}$; IR spectrum, $v$, $\mathrm{cm}^{-1}$ : $3004(=\mathrm{C}-\mathrm{H}$ arom. $), 1596(\mathrm{C}=\mathrm{N}), 1577,1448(\mathrm{C}=\mathrm{C}$ arom.), 1243 (C-O), 523 (Zn-O), 488 (Zn-N); ${ }^{1} \mathrm{H}-\mathrm{NMR}$ spectrum $\left(300 \mathrm{MHz}, \quad\right.$ DMSO-d $\left.{ }_{6}\right) \quad \delta_{\mathrm{H}}, \quad$ ppm: 6.49-6.54 $(\mathrm{J}=6.51 \mathrm{~Hz}, 1 \mathrm{H}, \mathrm{t}), 6.69-6.72(\mathrm{~J}=6.71 \mathrm{~Hz}, 1 \mathrm{H}, \mathrm{d}) 7.15-7.30$ $(1 \mathrm{H}, \mathrm{m}), 7.35-7.50(2 \mathrm{H}, \mathrm{m}), 7.88-7.91(\mathrm{~J}=7.9 \mathrm{~Hz}, 1 \mathrm{HAr}, \mathrm{q})$, $9.01\left(1 \mathrm{H}\right.$, ammine, s); ${ }^{13} \mathrm{C}-\mathrm{NMR}$ spectrum $(75 \mathrm{MHz}$, DMSO- $\left.\mathrm{d}_{6}\right) \delta_{\mathrm{C}}$, ppm: 113.42-119.83, 163.29, 172.73; Calculated, \%: C 63.26; $\mathrm{H} 3.72 ; \mathrm{N}$ 7.38. $\mathrm{C}_{20} \mathrm{H}_{14} \mathrm{~N}_{2} \mathrm{O}_{2} \mathrm{Zn}$ (379.72). Found, \%: C 63.46; H 3.62; N 7.48.

The overall synthesis route form ligands to zinc complexes are given in Scheme 1.

\section{Anti-inflammatory studies}

Anti-inflammatory studies were carried out for the aldimine and $\mathrm{Zn}(\mathrm{II})$ complexes by minor modification of the bovine serum albumin (BSA) denature inhibition technique. ${ }^{17}$ "The synthesized aldimine and their $\mathrm{Zn}$ (II) complexes were administered with the standard drug diclofenac sodium taken at different doses of $10 \mathrm{mM}, 50 \mathrm{mM}, 100 \mathrm{mM}, 250 \mathrm{mM}$ and $500 \mathrm{mM}$ dissolved in water and dimethylformamide (DMF) with diluted phosphate buffer $(0.2 \mathrm{M}, \mathrm{pH}=7.4)$. About $4 \mathrm{~mL}$ of the obtained minimum concentration (less than $2.5 \%$ ) of all test solutions was mixed with $1 \mathrm{~mL}$ of $1 \mathrm{mM}$ bovine serum albumin solution in phosphate buffer. Further, the mixture was kept in an incubator at $37^{\circ} \mathrm{C}$ for $20 \mathrm{~min}$ and denaturation was kept by keeping the reaction mixture at $70{ }^{\circ} \mathrm{C}$ in a water bath for $30 \mathrm{~min}$; then, it could cool to room temperature and measured at $660 \mathrm{~nm}$ using UV/Visible spectrophotometry. The percentage of denaturing inhibition was measured for the control without the addition of drug and diclofenac sodium was employed as a standard drug. The percentage of albumin denature inhibition was calculated using Equation 1.

$$
\text { Albumin denature inhibition }(\%)=\left[1-A_{c} / A_{t}\right] \times 100 \text { (Eq. 1) }
$$

where $A_{c}$ and $A_{t}$ represent optical density (O.D.) of the test solution and control, respectively."

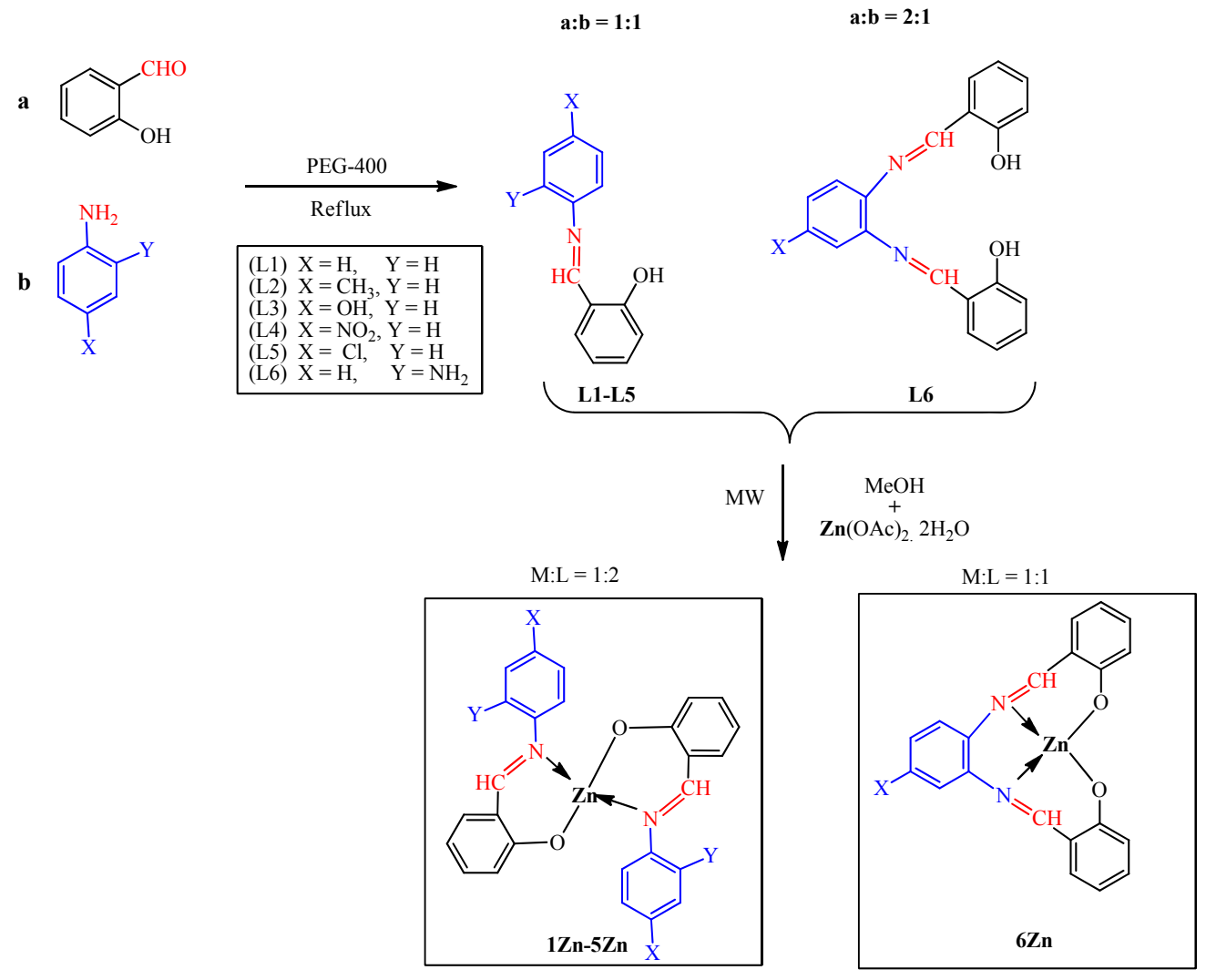

Scheme 1 - Synthesis of aldimine ligands and their corresponding zinc complexes. 


\section{Procedure for preparation \\ of solution for solubilization studies}

The solutions of the complexes $(1 \mathrm{Zn}-6 \mathrm{Zn})$ were prepared in distilled deionized water to investigate their conductometric and spectroscopic parameters. The aqueous solution of zinc complexes was the primary solution and it was further used for the preparation of secondary solutions by dissolving SDS (7-15 mM) in pre-micellar, micellar, and post-micellar concentrations $^{18}$.

\section{Apparatus and methods for solubilization studies}

\section{UV-Visible spectroscopy}

UV-Visible absorbance values of aqueous solutions of zinc complexes ( $1 \mathrm{mM}$ each) in the presence and absence of SDS were measured on computer interfaced double beam UVVisible spectrophotometer (Perkin Elmer, USA). The extent and nature of the interaction between complex molecules and surfactant were revealed by measuring simple and differential absorbance value recorded in square quartz cells $(10 \mathrm{~mm}$ thick; $1 \mathrm{~nm}$ slit width) at $298 \mathrm{~K}$ with accuracy control of $\pm 0.5 \mathrm{~K}$. In recording differential absorbance, the aqueous solution of $\mathrm{Zn}$ complex $(8.2 \mathrm{mM})$ was used as reference and solution of zinc complex in the presence of SDS was used in the sample cell. This absorbance data was used to measure the partitioning and binding parameters of solubilization. The equations for calculating these parameters are presented in equations 3-6.

\section{Partition and Binding Parameters}

The distribution of zinc complexes between aqueous and micellar media was governed by Partition law as proposed by Kawamura et al. to calculate partitioning coefficients using differential UV/Visible absorbance method. ${ }^{19}$

The differential absorbance $(\Delta \mathrm{A})$ was calculated using with relationship presented in equation 3 .

$$
\frac{1}{\Delta A}=\frac{1}{K_{C} \Delta A_{\infty}\left(C_{a}+C_{S}^{m 0}\right)}+\frac{1}{\Delta A_{\infty}}
$$

In Equation 5: $K_{c}$ is the partition constant; $C_{a}$ for concentration of zinc complexes; $\Delta \mathrm{A}_{\infty}$ is the value differential absorbance at infinite dilution. In the relationship $C_{S}^{m}=\mathrm{C}_{s}-\mathrm{CMC}_{\mathrm{o}} ; \mathrm{CMC}_{\mathrm{o}}$ is the $\mathrm{CMC}$ of SDS in aqueous medium and $C_{s}$ is representing the concentration of SDS used. Partitioning coefficient $\left(K_{x}\right)$ was calculated from the given expression, $\mathrm{n}_{w}=$ number of moles of water. The standard change in free energy of partition) $\left(\Delta G_{p}\right)$ was calculated with equation 4 whereas, the binding constant $\left(\mathrm{K}_{b}\right)$ was calculated from the equation 5 .

$$
\begin{gathered}
\Delta G_{p}=-R T \ln K_{x} \\
\frac{C_{S} C_{a}}{\Delta A}=\frac{C_{S}}{\Delta \in 1}+\frac{1}{K_{b} \Delta \in 1}
\end{gathered}
$$

$\mathrm{C}_{a}$ is representing the concentration of the metal complex. The standard binding free energy change $\left(\Delta G_{b}\right)$ was computed from equation 6 .

$$
\Delta G_{b}=-R T \ln K_{b}
$$

\section{Electrical conductivity (EC)}

Electrical conductivity parameters were studied with Hanna Cond. meter (HI-99301) at varying temperatures from 298 to $318 \mathrm{~K}(10 \mathrm{~K}$ increment rate $)$ with accuracy maintenance up to $\pm 0.5 \%$ and $\sim \pm 0.5 \mathrm{~K}$. The electrodes of the conductometer were coated with platinum black to avoid any possible polarizations and to measure conductivity in $0.01-$ $199.9 \mathrm{mS}$ range. The electrode was calibrated with $\mathrm{KCl}$ solution in the required concentration range from molar conductivity data.

\section{Thermodynamic Parameters}

This conductivity data was used to measure thermodynamic parameters of solubilization. The equations for calculating these parameters are presented equations 7-10.

(i) The extent of dissociation ( $\beta$ )

The ratio of the slopes of straight lines in the post-micellar and pre-micellar regions as shown in equation 7 gave the value of $\beta$.

$$
\beta=\frac{S_{2(\text { Post }- \text { micellar slope })}}{S_{1(\operatorname{Pr} e-\text { micellar slope })}}
$$

(ii) Free energy of micellization $\left(\Delta G_{m}^{0}\right)$ was computed by Eq. 8.

$$
\Delta G_{m}^{0}=(2-\beta) R T \ln X_{C M C}
$$

(iii) Entropy of micellization $\left(\Delta S_{m}\right)$ was calculated using equation 9.

$$
\Delta S_{m}=\frac{\Delta H_{m}-\Delta G_{m}^{0}}{T}
$$

(iv) Enthalpy of micellization $\left(\Delta H_{m}\right)$ was computed with help of the following equation 10 .

$$
\Delta H_{m}=-2.3(22 \beta) R T^{2}\left[\frac{\partial\left(\log X_{C M C}\right)}{\partial T}\right]_{P}
$$

In the above equations: $\beta$ : degree of dissociation, $\mathrm{X}_{\mathrm{CMC}}$ : mole fraction of surfactants at CMC R : universal gas constant $\left(\sim 8.314 \mathrm{Jmol}^{-1} \mathrm{~K}^{-1}\right)$; $\mathrm{T}:$ absolute temperature.

The values of CMC of surfactant and thermodynamic parameters are summarized in Table 5.

\section{CONCLUSIONS}

A series of amorphous $\mathrm{Zn}$ (II) complexes with aldimines derived from salicylaldehyde were synthesized and characterized. The aldimine acts as a bidentate ligand and coordinated to zinc metal 
through oxygen and azomethine nitrogen so the tetrahedral structure of complexes has been proposed. The coordination of ligand to $\mathrm{Zn}$ (II) ion confirmed by spectral studies (UV-Vis, FT-IR, ${ }^{1} \mathrm{H}$ and ${ }^{13} \mathrm{C}$ NMR, photoluminescence), elemental and thermal (TGA, DTG). The complexes showed strong blue-green emission upon UV irradiation in solid-state and in solution forms. The optical absorption data of the complexes was employed to determine the optical band gaps in the range of 2.35-3.90 eV representing good optical properties. The anti-inflammatory studies proved that the aldimines were found to be biologically active and their $\mathrm{Zn}$ (II) complexes show meaningfully greater anti-inflammatory activity as compared to the free ligands. Thus, after analysing their toxicity to human beings, their vast nature can be additionally beneficial to the pharmaceutical industry, as an antiinflammation agent. The solubilization of these complexes in sodium dodecyl sulphate (SDS) was also investigated. The thermodynamic parameters including free energy, enthalpy, and entropy of micellization were determined by electrical conductivity. The interaction of zinc complexes with sodium dodecyl sulphate (SDS) was studied with the help of UV-Visible spectroscopy and electrical conductivity. We claim to pioneer such micellar interactions of zin-aldimine complexes. Partition and binding constants, their corresponding free energies were investigated through simple and differential spectroscopy. The values of critical micellar concentration CMC obtained from UV/Visible spectroscopy and conductometry were found in close agreement.

Acknowledgements. The authors are thankful to the Department of Chemistry QAU Islamabad, Department of Chemistry IUB Bahawalpur and Pakistan Institute of Engineering and Applied Sciences Islamabad, for providing spectroscopic service.

\section{REFERENCES}

1. M. M. Shakdofa, M. H. Shtaiwi, N. Morsy and T. AbdelRassel, Main Group Chem., 2014, 13, 187-218.

2. J. Y. Mak, W. Xu, R. C. Reid, A. J. Corbett, B. S. Meehan, H. Wang, Z. Chen, J. Rossjohn, J. McCluskey and L. Liu, Nature Comm., 2017, 8, 1-13.

3. S. Gomez-Coca, E. Cremades, N. Aliaga-Alcalde and E. Ruiz, J. Am. Chem. Soc., 2013, 135, 7010-7018.

4. M. Pan, B. B. Du,Y. X. Zhu, M. Q. Yue, Z. W. Wei and C. Y. Su, Chem.-A Euro. J., 2016, 22, 2440-2451.

5. M. M. Abd-Elzaher, A. A. Labib, H. A. Mousa, S. A. Moustafa, M. M. Ali and A. A. El-Rashedy, Beni-Suef Univ. J. Basic Appl. Sci., 2016, 5, 85-96.

6. W. Zishen, L. Zhiping and Y. Zhenhuan, Trans. Metal Chem., 1993, 18, 291-294.

7. E. Yousif, A. Majeed, K. Al-Sammarrae, N. Salih, J. Salimon and B. Abdullah, Arab. J. Chem., 2017, 10, S1639-S1644.

8. M. Azam, S. I. Al-Resayes, A. Trzesowska-Kruszynska, R. Kruszynski, F. Shakeel, S. M. Soliman, M. Alam, M. R. Khan and S. M. Wabaidur, J. Molec. Struct., 2020, $1201,127177$.

9. C. Maxim, T. D. Pasatoiu, V. C. Kravtsov, S. Shova, C. A. Muryn, R. E. Winpenny, F. Tuna and M. Andruh, Inorg. Chim. Acta, 2008, 361, 3903-3911.

10. O. Kotova, S. Eliseeva, A. Averjushkin, L. Lepnev, A. Vaschenko, A. Y. Rogachev, A. Vitukhnovskii and N. Kuzmina, Russ. Chem. Bull., 2008, 57, 1880-1889.

11. G. Kumaravel, P. P. Utthra and N. Raman, Bioorg. Chem., 2018, 77, 269.

12. L. Armelao, S. Quici, F. Barigelletti, G. Accorsi, G. Bottaro, M. Cavazzini and E. Tondello, Coord. Chem. Rev., 2010, 254, 487-505.

13. R. Raciti, R. Bahariqushchi, C. Summonte, A. Aydinli, A. Terrasi and S. Mirabella, J. Appl. Phys., 2017, 121, 234304.

14. L. Viganor, O. Howe, P. McCarron, M. McCann and M. Devereux, Curr. Top. Med. Chem., 2017, 17, 1280-1302.

15. N. Raman, R. Jeyamurugan and J. Joseph, J. Iran. Chem. Res., 2010, 3, 83-95.

16. P. Nisar, N. Ali, L. Rahman, M. Ali and Z. K. Shinwari, J. Bio. Inorg. Chem. (JBIC), 2019, 24, 929-941.

17. M. Amiri, D. Ajloo, M. Fazli, A. Mokhtarieh, G. Grivani JBIC A. A. Saboury, J. Biomolec. Struct. Dynamics, 2018, 36, 3753-3772.

18. M. B. Taj, M. D. Alkahtani, U. Ali, A. Raheel, W. Alelwani, A. M. Alnajeebi, N. A. Babteen, S. Noor and H. Alshater, Molecules, 2020, 25, 4252.

19. M. Taj, A. Raheel, W. Alelwani, D. Hajjar, A. Makki, A. Alnajeebi, N. Babteen, S. Trrmizi and S. Noor, Russ. J. Gen. Chem., 2020, 90, 1533-1543. 
